Article

\title{
Production of Recombinant Antimicrobial Polymeric Protein Beta Casein-E 50-52 and Its Antimicrobial Synergistic Effects Assessment with Thymol
}

\author{
Shohreh Fahimirad ${ }^{1}$, Hamid Abtahi ${ }^{2, *}$, Seyed Hadi Razavi ${ }^{1}$, Houshang Alizadeh ${ }^{1}$ and \\ Mansour Ghorbanpour ${ }^{3}$ \\ 1 Agriculture and Natural Resources Biotechnology Department, University of Tehran, Karaj 31587-11167, \\ Iran; sh_fahimirad@yahoo.com (S.F.); srazavi@ut.ac.ir (S.H.R.); halizadeh@ut.ac.ir (H.A.) \\ 2 Molecular and Medicine Research Center, Arak University of Medical Sciences, Arak, Molecular and \\ Medicine Research Center, Arak University of Medical Sciences, Arak 38181-76941, Iran \\ 3 Department of Medicinal Plants, Faculty of Agriculture and Natural Resources, Arak University, \\ Arak 3815688349, Iran; m-ghorbanpour@araku.ac.ir \\ * Correspondence: abtahi@arakmu.ac.ir; Tel.: +98-913-114-6154
}

Academic Editor: Philippe Bulet

Received: 24 March 2017; Accepted: 11 May 2017; Published: 31 May 2017

\begin{abstract}
Accelerating emergence of antimicrobial resistance among food pathogens and consumers' increasing demands for preservative-free foods are two contemporary challenging aspects within the food industry. Antimicrobial packaging and the use of natural preservatives are promising solutions. In the present study, we used beta-casein-one of the primary self-assembly proteins in milk with a high polymeric film production capability-as a fusion partner for the recombinant expression of E 50-52 antimicrobial peptide in Escherichia coli. The $p E T 21 a-B C N-E$ 50-52 construct was transformed to E. coli BL21 (DE3), and protein expression was induced under optimized conditions. Purified protein obtained from nickel affinity chromatography was refolded under optimized dialysis circumstances and concentrated to $1600 \mu \mathrm{g} / \mathrm{mL}$ fusion protein by ultrafiltration. Antimicrobial activities of recombinant BCN-E 50-52 performed against Escherichia coli, Salmonella typhimurium, Listeria monocytogenes, Staphylococcus aureus, Aspergillus flavus, and Candida albicans. Subsequently, the synergistic effects of BCN-E 50-52 and thymol were assayed. Results of checkerboard tests showed strong synergistic activity between two compounds. Time-kill and growth kinetic studies indicated a sharp reduction of cell viability during the first period of exposure, and SEM (scanning electron microscope) results validated the severe destructive effects of BCN E 50-52 and thymol in combination on bacterial cells.
\end{abstract}

Keywords: antimicrobial activity; beta-casein; E 50-52; synergism; thymol

\section{Introduction}

The adverse impacts of chemical antimicrobial compounds as food preservatives on human health, growing food pathogen resistance to commonly-used antimicrobial agents, and increasing interest in natural food preservatives are the primary issues persuading researchers to find novel natural antimicrobial compounds as food preservatives [1]. Antimicrobial packaging systems serve as a strong obstacle for microbial agents, and extend food shelf life while diminishing preservative compound utilization. Therefore, novel antimicrobial polymers with natural sources have received considerable attention [2]. Bacteriocins are bacterial antimicrobial peptides which have been exploited as biopreservatives in the food industry for a hundred years [3]. Bacteriocins have been divided into four classes: Class II consists of three subgroups on the basis of their primary structure. 
The YGNGV-conserved motif, a disulphide bond linkage, and significant inhibitory impacts on Listeria sp. are most prominent in Class IIa bacteriocins, typically [4]. Bacteriocin E 50-52, with net charge of +2 , produced by Enterococcus faecium belongs to class Ila bacteriocin [5]. The wide antibacterial spectrum, successful inhibition of antibiotic-resistant bacterial strains, heat stability, and the quality of being recognized as safe makes Bacteriocin E 50-52 a great candidate as a natural antimicrobial food preservative [6]. Bacteriocin derivation from natural bacterial sources is time-consuming, laborious, and costly. Solid-phase chemical synthesis provides small amounts of peptides, but biotechnological approaches are able to efficiently produce higher quantities [7]. However, using microbial hosts for the production of antimicrobial peptides leads to inconsiderable yield.

The recombinant production of antimicrobial peptides in bacterial cells using different kinds of carriers has led to significant production [8]. Beta-casein $(\beta-\mathrm{CN})$ is one of four main types of casein, a major milk protein [9]. $\beta-C N$ 's homodimerization activity and amphiphilic structure cause the formation of micelles in aqueous solutions $[10,11]$. $\beta$-CN's abilities in the formation of polymeric films were reported in separate studies [12-14].

In this study, we applied beta-casein as a carrier for the expression of E 50-52 in E. coli to create an antimicrobial polymeric monomer for further applications in food packaging. The antimicrobial activities of the fused BCN-E 50-52 against common food photogenes were assayed, and its synergistic effects with thymol as a food-grade monoterpene were calculated.

\section{Results}

\subsection{Expression of BCN E 50-52 in E. coli BL21}

Protein production in various tested induction conditions was analyzed by SDS-PAGE. The greatest yield was achieved by applying $1.5 \times \mathrm{NB}$ and $0.5 \mathrm{mM}$ isopropyl thio $\beta$-D-galactosidase (IPTG). Overnight incubation of induced medium under $200 \mathrm{rpm}$ shaking at $24{ }^{\circ} \mathrm{C}$ was the most convenient condition. The produced $35 \mathrm{kDa}$ protein after $24 \mathrm{~h}$ and $2 \mathrm{~h}$ of induction are indicated by corresponding arrows in Figure 1a.

\subsection{Purification and Refolding of BCN E 50-52}

SDS-PAGE was used to analyze the quality and quantity of purified proteins by nickel nitrilotriacetic acid-agarose (Ni-NTA; Qiagen, Valencia, Spain; Alameda, CA, USA). Then, various changes in the durations and times of the purification steps were applied to gain much more purified protein without any extra bands (Figure 1b).

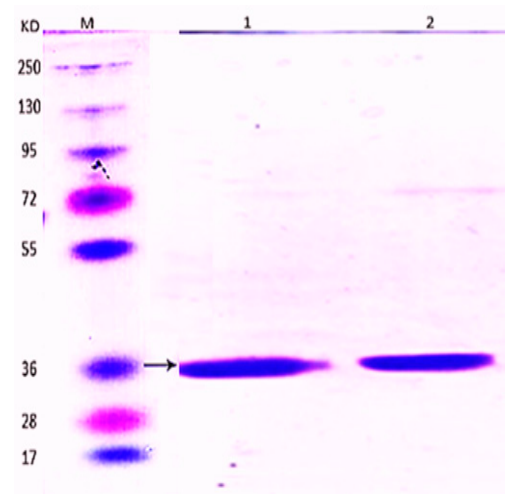

(a)

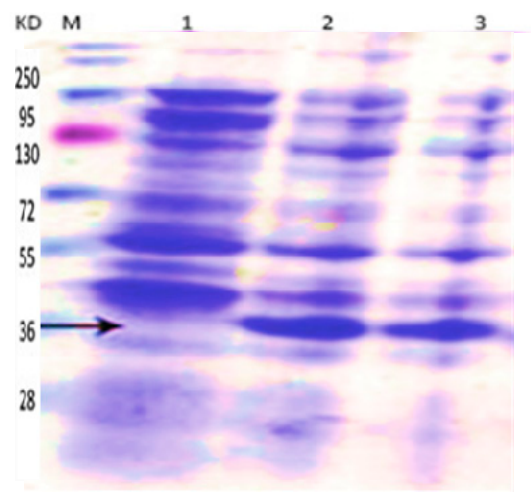

(b)

Figure 1. (a) Expression of BCN-E 50-52 in E. coli BL21. M: size marker; lane 1: total protein before induction; lane 2: total protein $2 \mathrm{~h}$ after induction; lane 3: total protein $24 \mathrm{~h}$ after induction. (b) Purification and refolding of BCN-E 50-52. M: size marker; lane 1: fusion protein retrieved by nickel affinity chromatography; lane 2: protein after refolding. 
The best dialysis conditions were chosen based on the MIC (minimum inhibitory concentration) assay against $S$. aureus and E. coli. The results of dialysis in phosphate-buffered saline (PBS) buffers at different $\mathrm{pHs}$ revealed that low $\mathrm{pH}(\mathrm{pH}=4.5$ and $\mathrm{pH}=5)$ was the most effective for protein yields. Proteins was dialyzed in PBS-based exchanging buffers contained a complex of $0.5 \mathrm{mM}$ cysteine and $0.05 \mathrm{mM}$ cystine at $\mathrm{pH}=4.5$. BCN-E 50-52 concentration after the dialysis procedure was about $200 \mu \mathrm{g} / \mathrm{mL}$, which was not sufficient for further assays. The problem was solved by utilizing Amicon centrifuging filters, yielding proteins with $1600 \mu \mathrm{g} / \mathrm{mL}$ concentration.

\subsection{Antibacterial and Antifungal Activities}

The MIC values of BCN-E 50-52 and thymol-alone and in combination-against the test bacteria and fungi are presented in Table 1.

Table 1. The minimum inhibitory concentrations (MICs) of BCN-E 50-52, thymol, and their combinations against different microorganisms.

\begin{tabular}{|c|c|c|c|c|c|c|c|c|}
\hline \multirow[b]{2}{*}{ Microorganism } & \multicolumn{8}{|c|}{ MIC ( $\mu \mathrm{g} / \mathrm{mL})$} \\
\hline & $\begin{array}{l}(\mathrm{BCN}-\mathrm{E} \\
50-52)_{\mathrm{A}}\end{array}$ & $\begin{array}{l}(\mathrm{BCN}-\mathrm{E} \\
50-52)_{\mathrm{C}}\end{array}$ & $\mathrm{FIC}_{\mathrm{A}}$ & Thymol $_{B}$ & Thymol $_{\mathrm{c}}$ & $\mathrm{FIC}_{\mathrm{B}}$ & FIC $_{C}$ & Interpretation \\
\hline \multicolumn{9}{|l|}{ Gram-negative } \\
\hline E. coli & 25 & 8 & 0.031 & 128 & 16 & 0.125 & 0.156 & synergistic \\
\hline S. typhimurium & 256 & 4 & 0.015 & 128 & 32 & 0.25 & 0.265 & synergistic \\
\hline \multicolumn{9}{|l|}{ Gram-positive } \\
\hline S. aureus & 256 & 2 & 0.0078 & 128 & 16 & 0.125 & 0.132 & synergistic \\
\hline L. monocytogenes & 256 & 2 & 0.0078 & 128 & 64 & 0.5 & 0.507 & partial synergy \\
\hline \multicolumn{9}{|l|}{ Fungi } \\
\hline C. albicans & 256 & 8 & 0.031 & 64 & 32 & 0.5 & 0.515 & partial synergy \\
\hline A. flavus & - & - & - & 128 & 64 & 0.5 & - & non-synergistic \\
\hline
\end{tabular}

The table demonstrates MIC values for each compound alone (subscript A for BCN E 50-52, and subscript B for thymol), the MIC value for each compound in combination (subscript C), the individual FIC (fractional inhibitory concentration) values, the combined FIC value (FIC $\mathrm{C}_{\mathrm{C}}$ ), and the synergism interpretation. The different test microorganisms illustrated distinct susceptibility to each compound individually and in combined forms. Overall, MIC tests indicated that BCN E 50-52 showed moderate antimicrobial activity against most tested microorganisms and no antimicrobial activity against $A$. flavus. Thymol (MIC $128 \mu \mathrm{g} / \mathrm{mL}$ ) was the same for all tested microorganisms, except the $\mathrm{MIC}$ of $64 \mu \mathrm{g} / \mathrm{mL}$ for $A$. flavus. The combination of thymol and BCN E 50-52 devalued the BCN E 50-52 MIC against most of the tested organisms. The most intense synergisms between BCN E 50-52 and thymol were shown against $S$. aureus and L. monocytogenes, which recorded up to a 128 -fold decline in the BCN E 50-52 MIC (the FIC $_{\mathrm{A}}$ value = 0.0078) (Figure 2). The FIC index reveals a kind of synergy between BCN E 50-52 and thymol in all test organisms, and no effects for $A$. flavus (Table 1). 


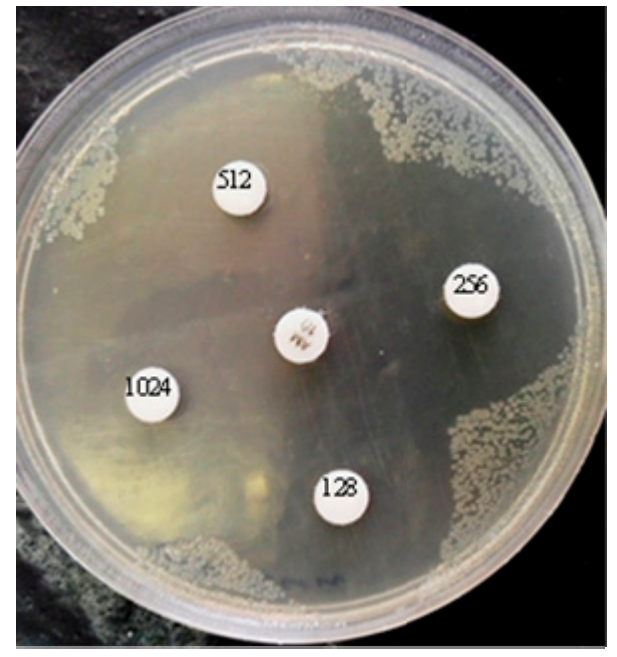

(a)

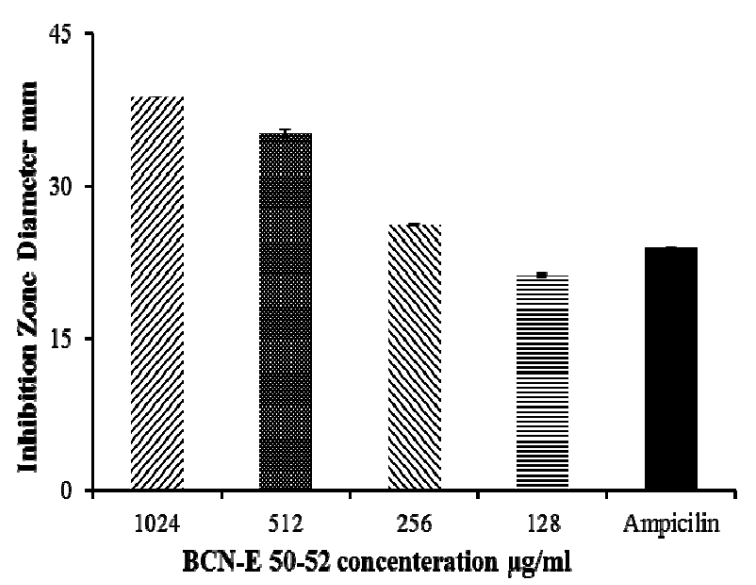

(c)

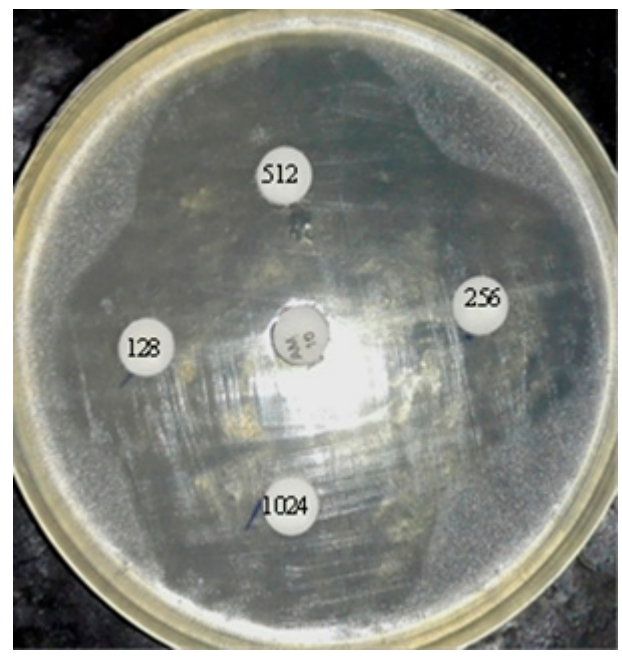

(b)

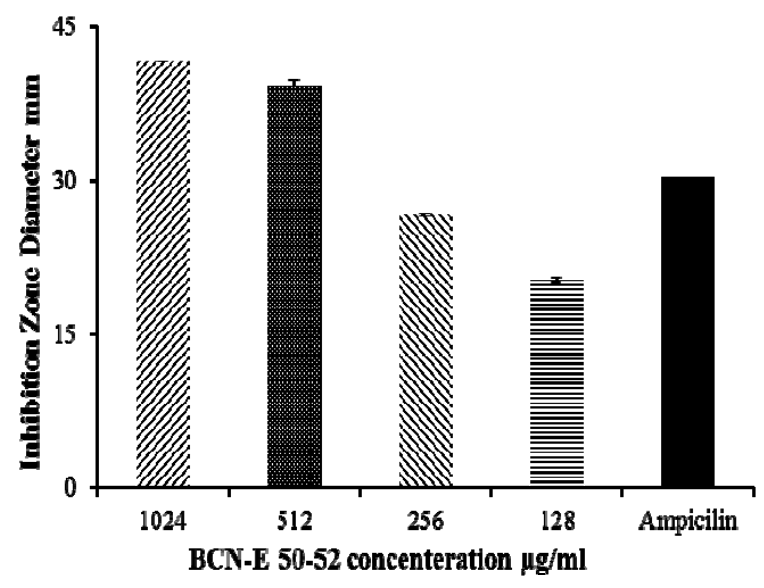

(d)

Figure 2. Agar disk diffusion of BCN E 50-52 against (a) E. coli and (b) S. aureus. BCN E 50-52 concentrations are written on disks in $\mu \mathrm{g} / \mathrm{mL}$. Inhibition zone diameters of BCN E 50-52 against (c) E. coli and (d) S. aureus.

\subsection{Bactericidal and Fungicidal Activities}

The results of the minimum bactericidal concentration (MBC) studies are summarized in Tables 2-4. The separate MBC tests of BCN E 50-52 and thymol against the tested bacteria indicated no bactericidal activity of BCN E 50-52 and a faint bactericidal activity of thymol. The calculated MBC (minimum bactericidal concentrations)/MIC values illustrated the bacteriostatic activity of both compounds against all test bacterial species. The resultant MFC (minimum fungicidal concentration)/MIC confirmed the fungistatic activity of each individual compound against C. albicans (Table 2).

The individual MBC values of each compound declined in combination tests. More than four-fold devaluation of BCN E 50-52 MBC was recorded against E. coli, S. aureus, and L. monocytogenes in combination with thymol than in individual assays (fractional bactericidal concentration, $\mathrm{FBC}=0.25$ ). MBC values of thymol were reduced two- to four-fold compared to the compound's individual employment. BCN E 50-52 MFC values for C. albicans were reduced by more than two-fold, while there was no synergistic effect between thymol and BCN E 50-52 against $A$. flavus (Table 3). The synergistic effects of BCN E 50-52 and thymol are shown in Table 4. The FBCI (fractional bactericidal concentration 
index) and the interpretations for the activities of this combination against the test bacteria are recorded as synergistic and partial synergy.

Table 2. The minimum bactericidal concentrations and the minimum fungicidal concentrations of $\mathrm{BCN}$ E 50-52 and thymol.

\begin{tabular}{|c|c|c|c|c|c|c|}
\hline \multirow{3}{*}{ Microorganism } & \multicolumn{6}{|c|}{ Separated Studies } \\
\hline & \multicolumn{2}{|c|}{$(B C N$ E 50-52) } & \multirow{2}{*}{ Interpretation } & \multicolumn{2}{|c|}{ Thymol $_{B}$} & \multirow{2}{*}{ Interpretation } \\
\hline & MBC & MBC/MIC & & MBC & MBC/MIC & \\
\hline \multicolumn{7}{|l|}{ Gram-negative } \\
\hline E. coli & $>512$ & 4 & bacteriostatic & 512 & 4 & bacteriostatic \\
\hline S. typhimurium & $>512$ & $>4$ & bacteriostatic & $>512$ & $>4$ & bacteriostatic \\
\hline \multicolumn{7}{|l|}{ Gram-positive } \\
\hline S. aureus & $>512$ & 8 & bacteriostatic & 512 & 4 & bacteriostatic \\
\hline L. monocytogenes & $>512$ & $>4$ & bacteriostatic & 512 & 4 & bacteriostatic \\
\hline \multicolumn{7}{|l|}{ Fungi } \\
\hline & MFC & MFC/MIC & & MFC & MFC/MIC & \\
\hline C. albicans & $>512$ & $>4$ & fungistatic & 256 & 4 & fungistatic \\
\hline A. flavus & - & - & No effects & 256 & 4 & fungistatic \\
\hline
\end{tabular}

Values represent the mean of three replications. MBC: minimum bactericidal concentration; MFC: minimum fungicidal concentration.

Table 3. The minimum bactericidal concentrations and the minimum fungicidal concentrations of BCN E 50-52 and thymol in combination.

\begin{tabular}{|c|c|c|c|c|c|c|}
\hline \multirow{3}{*}{ Microorganism } & \multicolumn{6}{|c|}{ Synergism Study } \\
\hline & \multicolumn{2}{|c|}{$(\mathrm{BCN}$ E 50-52) } & \multirow{2}{*}{ Interpretation } & \multicolumn{2}{|c|}{ Thymol $_{c}$} & \multirow{2}{*}{ Interpretation } \\
\hline & MBC & $\overline{\mathrm{MBC} / \mathrm{MIC}}$ & & MBC & $\overline{M B C / M I C}$ & \\
\hline \multicolumn{7}{|l|}{ Gram-negative } \\
\hline E. coli & 128 & 16 & bacteriostatic & 128 & 8 & bactericidal \\
\hline S. typhimurium & 128 & 64 & bacteriostatic & 128 & 4 & bacteriostatic \\
\hline \multicolumn{7}{|l|}{ Gram-positive } \\
\hline S. aureus & 16 & 64 & bacteriostatic & 128 & 4 & bacteriostatic \\
\hline L. monocytogenes & 128 & 64 & bacteriostatic & 256 & 8 & bacteriostatic \\
\hline \multicolumn{7}{|l|}{ Fungi } \\
\hline & & MFC/MIC & & MFC/MIC & & \\
\hline C. albicans & 256 & 32 & fungistatic & 256 & 16 & fungistatic \\
\hline A. flavus & - & - & - & 256 & 4 & fungistatic \\
\hline
\end{tabular}

Values represent the mean of three replications.

Table 4. The fractional bactericidal concentration index (FBCI) of synergism study.

\begin{tabular}{lcccc}
\hline \multirow{2}{*}{ Organism } & \multicolumn{3}{c}{ FBC } & Interpretation \\
\cline { 2 - 3 } & BCN E 50-52 & Thymol $_{\mathbf{C}}$ & FBCI & \\
\hline Gram-negative & & & & \\
$\begin{array}{l}\text { E. coli } \\
\text { S. typhimurium }\end{array}$ & 0.25 & 0.25 & 0.5 & partial synergy \\
pram-positive & 0.25 & 0.25 & 0.5 & part synergy \\
\hline $\begin{array}{l}\text { S. aureus } \\
\text { L. monocytogenes }\end{array}$ & 0.25 & 0.25 & 0.5 & partial synergy \\
\hline Fungi & 0.25 & 0.5 & 0.75 & partial synergy \\
$\begin{array}{l}\text { C. albicans } \\
\text { A. flavus }\end{array}$ & 0.5 & 1 & & \\
\hline & - & 1 & 1.5 & no synergy \\
\hline
\end{tabular}

Values represent the mean of three replications. 


\subsection{Agar Disk Diffusion}

Confirming the MIC results, the antimicrobial activity of BCN E 50-52 with different concentrations was assayed against E. coli and S. aureus (Figure 2). The test concentrations were equal to $1 / 2 \mathrm{MIC}$, MIC, $2 \times$ MIC, and $4 \times$ MIC for each bacterium. Diameters of the inhibition zones corresponding to different concentrations of BCN E 50-52 are shown in Figure 2. The qualitative data of agar disk diffusion after statistical analysis were compared to the control inhibition zone (ampicillin disk, $10 \mu \mathrm{g} / \mathrm{mL}$ ) according to the CLSI recommendation standard. The disks containing $4 \times$ MIC, MIC, and $2 \times$ MIC concentrations of BCN E 50-52 against both bacteria created inhibition zones in the range of susceptibility. Both bacterial inhibition zones for 1/2 MIC concentration of BCN E 50-52 were assigned to the resistance range (Figure 2).

\subsection{Time-Kill Curves}

The results of the time-kill assay for E. coli and S. aureus are presented in terms of the changes in the $\log _{10} \mathrm{CFU} / \mathrm{mL}$ of viable cells. Results of time-kill synergy studies are shown in Figure 3 . The number of viable $E$. coli cells decreased sharply, with more than five reductions in $\log _{10} \mathrm{CFU} \mathrm{mL}-1$ by the combination of BCN E 50-52 and thymol at $2 \times$ MIC within $40 \mathrm{~min}$, and complete cell death occurred within $60 \mathrm{~min}$. The test compound combinations achieved complete annihilation for S. aureus within $60 \mathrm{~min}$, while BCN E 50-52 and thymol caused three and four reductions in $\log _{10} \mathrm{CFU} \mathrm{mL} \mathrm{C}^{-1}$ viable cells gradually for both test bacteria and could not inhibit the cell growth thoroughly within the first $120 \mathrm{~min}$ (Figure 3).

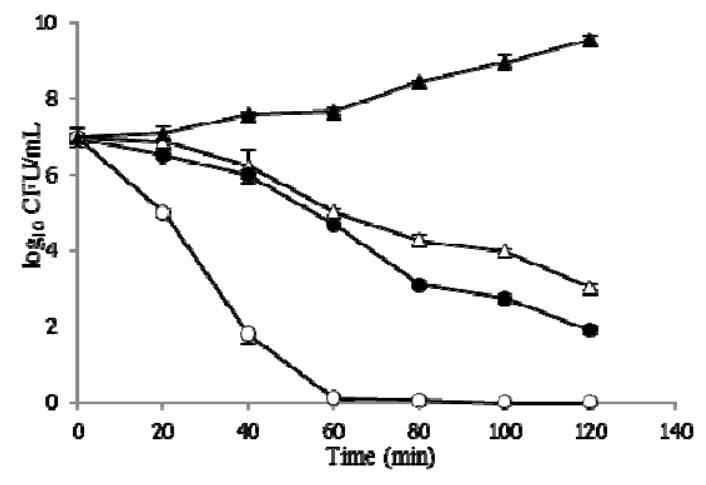

(a)

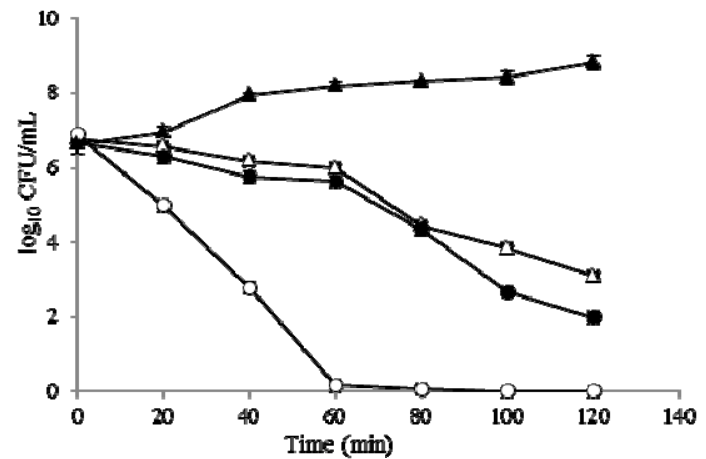

(b)

Figure 3. Bacterial-killing kinetics of BCN E 50-52 and thymol at $2 \times \mathrm{MIC}$ against E. coli and S. aureus. (a) E. coli; control (filled triangles), BCN E 50-52 $512 \mu \mathrm{g} / \mathrm{mL}$ (filled circles), thymol $256 \mu \mathrm{g} / \mathrm{mL}$ (open triangles), BCN E 50-52 $512 \mu \mathrm{g} / \mathrm{mL}$ and thymol $256 \mu \mathrm{g} / \mathrm{mL}$ (open circles); (b) S. aureus; control (filled triangles), BCN E 50-52 $512 \mu \mathrm{g} / \mathrm{mL}$ (filled circles), thymol $256 \mu \mathrm{g} / \mathrm{mL}$ (open triangles), BCN E $50-52512 \mu \mathrm{g} / \mathrm{mL}$ and thymol $256 \mu \mathrm{g} / \mathrm{mL}$ (open circles).

\subsection{Growth Kinetic Curves}

In order to determine the mechanism of action of BCN E 50-52 against S. aureus and E. coli, the turbidity of bacterial cultures exposed to $2 \times$ MIC of BCN E 50-52 and thymol were recorded over time by a spectrophotometer. BCN E 50-52 and thymol separately caused more than $50 \%$ reductions in the turbidity of both bacterial suspensions after $4 \mathrm{~h}$ and maintained this rate for $8 \mathrm{~h}$ (Figure 4 ). The combination of BCN E 50-52 and thymol had much greater success in the reduction of more than $50 \%$ of $S$. aureus suspensions' turbidity within the first hour, over $80 \%$ and $95 \%$, declining after $2 \mathrm{~h}$ and $4 \mathrm{~h}$, respectively. The E. coli suspension exposed to the combination of test compounds indicated $50 \%$, $85 \%$, and $95 \%$ density reductions occurring at 1, 2, and $4 \mathrm{~h}$, respectively (Figure 4 ). 


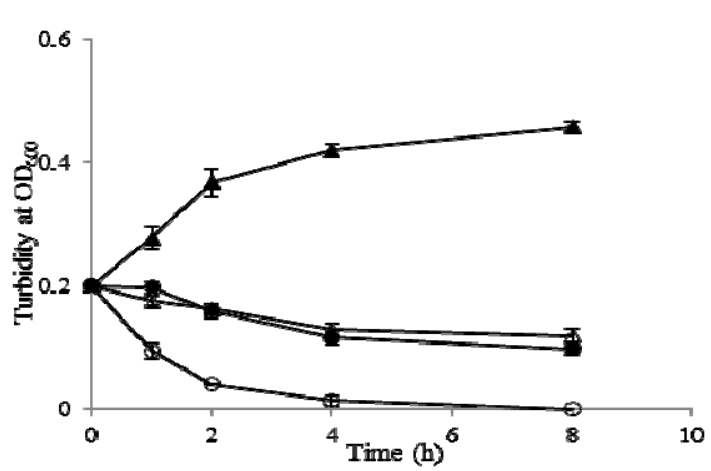

(a)

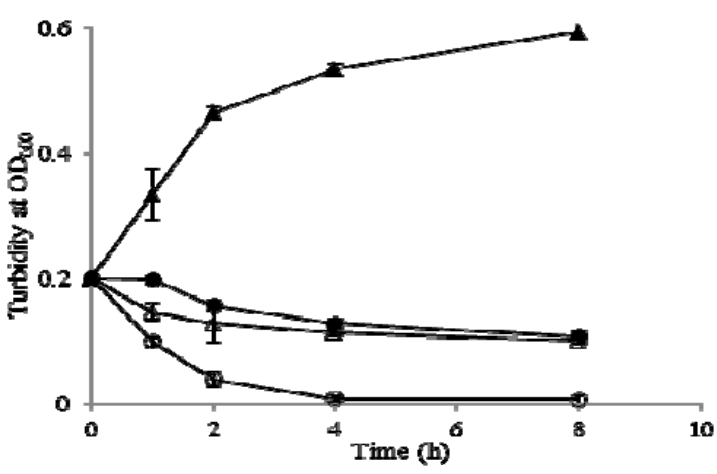

(b)

Figure 4. Bacterial growth kinetics of BCN E 50-52 and thymol at $2 \times \mathrm{MIC}$ against E. coli and S. aureus. (a) E. coli; control (filled triangles), BCN E 50-52 $512 \mu \mathrm{g} / \mathrm{mL}$ (filled circles), thymol $256 \mu \mathrm{g} / \mathrm{mL}$ (open triangles), BCN E 50-52 $512 \mu \mathrm{g} / \mathrm{mL}$ and thymol $256 \mu \mathrm{g} / \mathrm{mL}$ (open circles); (b) S. aureus; control (filled triangles), BCN E 50-52 $512 \mu \mathrm{g} / \mathrm{mL}$ (filled circles), thymol $256 \mu \mathrm{g} / \mathrm{mL}$ (open triangles), BCN E 50-52 $512 \mu \mathrm{g} / \mathrm{mL}$ and thymol $256 \mu \mathrm{g} / \mathrm{mL}$ (open circles). OD: optical density.

\subsection{SEM Microscopy}

E. coli cells treated with a combination of thymol and BCN E 50-52 at FIC values illustrated complete cell deformation and cell wall destruction after $2 \mathrm{~h}$ (Figure $4 \mathrm{~b}$ ). Indicating similar symptoms, membrane piercing and subsequent cytoplasmic material leakage were obvious morphological changes of $S$. aureus cells after treating for $2 \mathrm{~h}$ with thymol and BCN E 50-52 at FIC values (Figure 4d). These results confirm rapid antimicrobial activities of BCN E 50-52 in combination with thymol and validate the time-kill and growth curve results.

\section{Discussion}

The emergence of a vast spectrum of resistance to common antimicrobial agents among microorganisms is turning into a unanimous global health concern. Research into new kinds of antimicrobial compounds is receiving much more attention. E 50-52, as a bacteriocin, is a food-grade strong antimicrobial peptide with diverse antimicrobial killing activities [5]. In addition to the development of antimicrobial edible films are active research fields in the food industry for employing natural sources as food preservatives [15]. Beta-casein's ability to form edible polymeric films and attach to other polymers has been previously proved $[16,17]$. In the present study, we describe the use of beta-casein as a fusion partner for the expression of E 50-52 in Escherichia coli BL21 (DE3) (Figure 5). It has been proved that the free N-terminal hydrophilic domain of Bacteriocin Class IIa plays the main role in attaching to bacterial cells and cell lysis process initiation $[5,18]$. $\beta-\mathrm{CN}$ fusing to the $\mathrm{E}$ 50-52 N-terminal decreased its antimicrobial activities and caused a more soluble expression of $\mathrm{E}$ 50-52 in a susceptible bacterial host. However, decreasing the IPTG ratio to $0.5 \mathrm{mM}$, reducing the incubation temperature to $24{ }^{\circ} \mathrm{C}$, and extending the induction time to $24 \mathrm{~h}$ were the most efficient conditions for recombinant protein production (Figure 1). While there were significant decrements in E 50-52 antimicrobial intensity in the fusion to $\mathrm{BCN}$, antimicrobial test results illustrated that BCN did not thoroughly hamper E 50-52 antimicrobial potency. Setting up the refolding process in an acidic buffer $(\mathrm{pH}=4.5,5)$ and applying the buffer including cysteine and cystin, followed by protein purification, boosted BCN E 50-52's antimicrobial activation. In silico estimation of BCN E 50-52 charge over the $\mathrm{pH}$ range confirmed that the charge of BCN E 50-52 at low $\mathrm{pH}(4,4.5$, and 5) is much more positive $(23.4,15.9$, and 9.1). The more positive net charge of recombinant BCN E 50-52 prompted its ability to attach to bacterial cell walls with negative charge [19]. There was accommodation between the disk diffusion-registered data and MIC results (Figure 2). Thus, bacteria were resistant to BCN E 50-52 sub-MIC, and the diameter of the inhibition zones increased according to 
ascending BCN E 50-52 concentration of the disks. Thymol is an important GRAS (generally recognized as safe) natural antimicrobial compound [20,21]. In order to promote BCN E 50-52 antimicrobial activities, the synergistic effects of this protein with thymol were assessed. The combination of the two compounds significantly devalued the compounds' MIC and MBC (Table 1). The FICI and FBCI for most test microorganisms indicated at least additive efficacy (Tables 1 and 4). Bacterial killing kinetics of BCN E 50-52, thymol, and their combination were conducted to survey the compounds' pace of action during the first minutes of application. The accelerating force of thymol to BCN E 50-52 function was obvious (Figure 3).

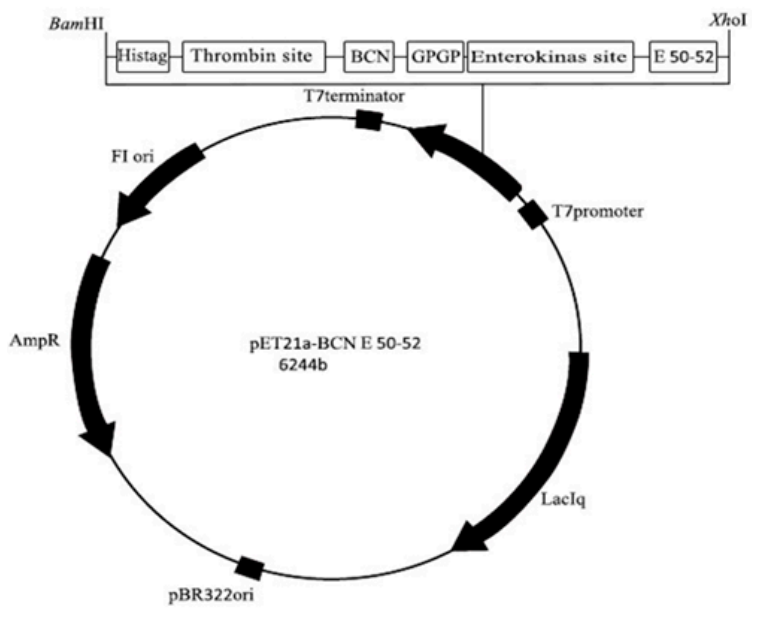

Figure 5. Design of the expression vector $p E T 21 a-B C N$ E 50-52. BCN: beta casein. GPGP: Double repeat of Glycine Proline as a flexible linker between two different proteins.

Overall, all performed antimicrobial tests demonstrated substantial antimicrobial activities of BCN E 50-52 and thymol in combination with each other. Bacteriocins destabilize bacterial cells by piercing their membranes and, consequently cause cell lysis [5]. Thymol is capable of penetrating into the lipid assemblies and damaging lipid membranes [22]. Creating primary disorders in the cell membrane by each compound enhances their efficiency in expanding cell leakage with much lower concentrations. SEM analysis indicated drastic disruptions in the cell walls by piercing and rupturing of the outer membranes and severe lysis of cells incubated with BCN E 50-52 and thymol combinations at FIC values (Figure 6).

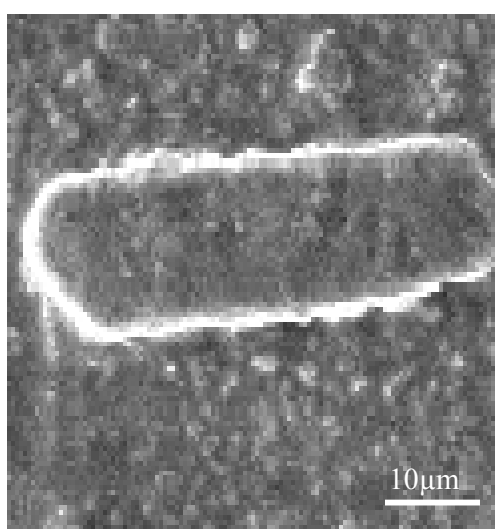

(a)

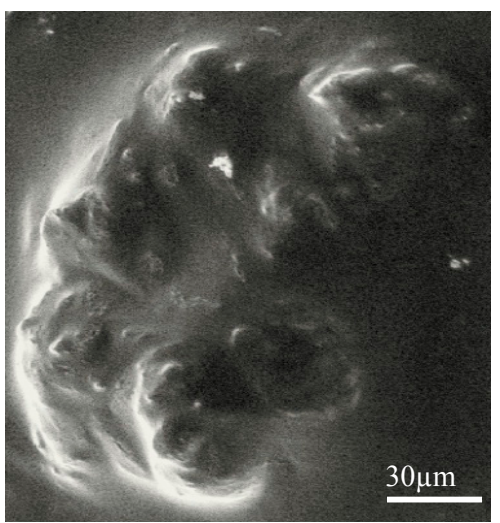

(b)

Figure 6. Cont. 


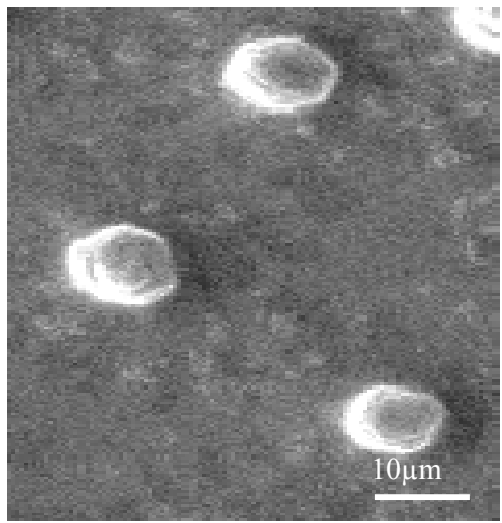

(c)

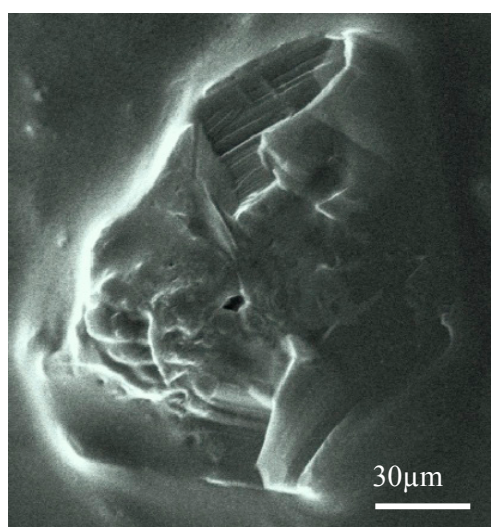

(d)

Figure 6. (a) SEM micrographs of untreated E. coli; (b) E. coli cell treated with a combination of BCN E 50-52 and thymol at FIC values; (c) SEM micrographs of untreated S. aureus; (d) S. aureus cell treated with a combination of BCN E 50-52 and thymol at FIC values.

\section{Materials and Methods}

\subsection{Materials and Chemicals}

Ampicillin, beta-casein, brain-heart infusion media (BHIB and BHIA), dimethyl sulfoxide, Mueller Hinton media (MHB and MHA), RPMI-1640, Sabouraud dextrose agar, resazurin sodium salt, and thymol were purchased from Sigma Aldrich Co. (St. Louis, MO, USA). All other chemicals used were of analytical grade.

\subsection{Bacterial Strains}

The antibacterial activities were assessed against four different food spoilage microorganisms: Two Gram-negative strains, including Escherichia coli ATCC 25922 and Salmonella enterica serovar Typhimurium ATCC 14028, and two Gram-positive strains, including Listeria monocytogenes ATCC 19115 and Staphylococcus aureus 29213. Antifungal activity was evaluated against Aspergillus flavus ATCC 204304 and Candida albicans ATCC 76615. Escherichia coli BL21 (DE3) was used as the recombinant protein expression host.

\subsection{Construction of the Expression Vector pET21a-BCN E 50-52}

The entire gene sequence, which contains the $5^{\prime}$ Bam $\mathrm{H} \mathrm{I}$, histidin tag, thrombin cleavage site, bovine beta-casein sequence ( $\beta-\mathrm{CN})$ (EMBL: M16645), GP linker, an enterokinase cleavage site, an E 50-52 corresponding sequence (UniProt: P85148), and Xho I 3' were designed and codon-optimized for E. coli expression. The whole construct was synthesized by Biomatik Company (Cambridge, ON, Canada). The synthesized DNA (EMBL: LT795121) was inserted into the plasmid pET21a (Novagene) as the expression vector (Figure 6).

\subsection{Expression of BCN E 50-52 in E. coli BL21}

Competent Escherichia coli BL21 (DE3) were prepared based on standard protocols, and were transformed by $p E T 21 a-B C N E$ 50-52 [23,24]. One of the recombinant colonies grown on plates containing ampicillin was incubated in $2 \mathrm{~mL} \mathrm{NB}$ medium containing $100 \mu \mathrm{g} / \mathrm{mL}$ ampicillin at $37^{\circ} \mathrm{C}$. Then, $300 \mu \mathrm{L}$ of overnight culture was inserted in $50 \mathrm{~mL}$ NB broth $(100 \mu \mathrm{g} / \mathrm{mL}$ ampicillin), and incubated at $37^{\circ} \mathrm{C}$ at $220 \mathrm{rpm}$. The cells' optical density at $600 \mathrm{~nm}$ were measured occasionally, and when the culture turbidity was equal to 0.6 , isopropyl thio $\beta$-D-galactosidase (IPTG) (1 mM) was added to induce protein expression. Four hours after induction, whole induced transformed bacteria were harvested by centrifugation at $5000 \mathrm{rpm}$ for $20 \mathrm{~min}$ and the pellets were stored at $-20^{\circ} \mathrm{C}$ [25]. 
Various cultured media, different amounts of IPTG, alternative incubating temperatures, and different incubation times were tested to achieve the highest protein expression efficiency.

\subsection{Purification of $B C N$ E $50-52$}

Denaturing conditions using $8 \mathrm{M}$ urea, followed by Ni-NTA agarose resin affinity chromatography (Qiagen, Alameda, CA, USA) were used for purification of the recombinant protein. SDS polyacrylamide gel electrophoresis (SDS-PAGE 12\%) was applied to assay the quality of the purified recombinant BCN E 50-52 protein. The quality of purified recombinant BCN E 50-52 protein was analyzed by the absorbance of 280 and $260 \mathrm{~nm}$ [26].

\subsection{Refolding Optimization of BCN E 50-52}

Using urea for protein purification denatures the active folding of proteins. So, the refolding process was done by applying prepared dialysis tubing, 10K molecular weight cut-off (MWCO) (Thermo Scientific SnakeSkin). Various $\mathrm{pH}(4.5,5,7,8,8.5)$ and different PBS-based exchanging buffers containing distinct amino acids (argenine, proline, and cysteine) were tested to gain the most efficient dialysis conditions [27]. The dialysis process was carried out at $4{ }^{\circ} \mathrm{C}$ for $24 \mathrm{~h}$. The best dialysis conditions were chosen based on their MIC results.

\subsection{Concentration of $B C N$ E 50-52}

A $10 \mathrm{kDa}$ pore-size Amicon centrifugal filter (Merck Millipore, Darmstadt, Germany) was used to concentrate the dialyzed protein.

\subsection{Preparation of Standardized Inoculum}

Bacterial inoculum preparation was done based on the CLSI standard protocol $\mathrm{MO}_{7}-\mathrm{A}_{10}$. Briefly, The selected isolated colonies were cultured in $\mathrm{BHI}$ broth and incubated at $37^{\circ} \mathrm{C}$ until the culture optical density OD at $600 \mathrm{~nm}$ was $0.1\left(1 \times 10^{8}\right.$ cells $\left./ \mathrm{mL}\right)$. Then, the suspensions were diluted 1:100 with $\mathrm{BHI}$ to achieve $1 \times 10^{6} \mathrm{CFU} / \mathrm{mL}$ [28].

\subsection{Preparation of the Thymol Solution}

Dimethyl sulfoxide (DMSO) was used as the thymol solvent at the final concentration of $1 \%(v / v)$. The initial concentration of thymol in solution was $1024 \mu \mathrm{g} / \mathrm{mL}$ [29].

\subsection{Determination of Antibacterial Minimum Inhibitory Concentration (MIC)}

CLSI protocol $\mathrm{MO}_{7}-\mathrm{A}_{10}$ was applied to calculate the MIC of BCN-E 50-52 and thymol against each tested organism [30]. Briefly, wells of the 96-well microplates from column 1:10 were filled by $50 \mu \mathrm{L}$ of BHI broth. Then, $50 \mu \mathrm{L}$ of the dialyzed recombinant $1024 \mu \mathrm{g} / \mathrm{mL}$ BCN-E 50-52 protein or $50 \mu \mathrm{L}$ of thymol solution were diluted in wells by two-fold serial dilutions in separated 96-well plates. Subsequently, $50 \mu \mathrm{L}$ of prepared bacterial inoculum was added to each well. Column 11, containing $100 \mu \mathrm{L}$ of bacterial inoculum, was considered as the positive growth control, and Column 12, with $100 \mu \mathrm{L}$ of the BHI, was the sterility control. After $24 \mathrm{~h}$ incubation at $37^{\circ} \mathrm{C}, 20 \mu \mathrm{L}$ of resazurin dyes $(0.02 \%(w / v))$ were added to each well and incubated again for $2 \mathrm{~h}$ [31]. The BCN-E 50-52 concentration in the last blue color well was scored as the MIC value. Ampicillin was used as the positive control, while $1024 \mu \mathrm{g} / \mathrm{mL}$ beta-casein solution was the negative control for BCN E 50-52 MIC assessment. Ampicillin and 1\% DMSO were positive and negative controls for thymol MIC study, respectively. All experiments were performed in triplicate.

\subsection{Determination of Minimum Bactericidal Concentration (MBC)}

After MIC assessment, $100 \mu \mathrm{L}$ of microplate blue wells corresponding to the MIC, and the above MIC values of BCN E 50-52 and thymol were plated on BHI agar. Following this, incubation of plates 
at $37^{\circ} \mathrm{C}$ for $24 \mathrm{~h}$ was conducted to indicate the lowest BCN E 50-52 and thymol concentrations that led to no colony growth, which was considered as the $\mathrm{MBC}$ value. The antibacterial activities were defined based on the $\mathrm{MBC} / \mathrm{MIC}$ ratio (MBC/MIC $=1$ or 2 bactericidal, $\mathrm{MBC} / \mathrm{MIC}=4$ or 16 bacteriostatic) [31].

\subsection{Determination of Antifungal MIC}

CLSI $\mathrm{M}_{27}-\mathrm{A}_{4}$ and $\mathrm{M}_{38}-\mathrm{A}_{3}$ protocols were used for antifungal susceptibility tests of BCN E 50-52 and thymol against $C$. albicans and A. flavus [32,33]. Briefly, $50 \mu \mathrm{L}$ culture preparations in RPMI 1640 with $2 \%$ glucose were inoculated into the flat-bottom wells of 96 -well microtiter plates. BCN E 50-52 and thymol, with initial concentrations $1024 \mu \mathrm{g} / \mathrm{mL}$, were added to wells by a two-fold serial dilution. Then, $50 \mu \mathrm{L}$ of $10^{3} \mathrm{CFU} / \mathrm{mL}$ prepared inoculum of $C$. albicans and $10^{4} \mathrm{CFU} / \mathrm{mL}$ conidiospores of A. flavus were poured per well. Plates were incubated at $35^{\circ} \mathrm{C}$ for $48 \mathrm{~h}$. Then, $20 \mu \mathrm{L}$ of the resazurin solution was added to each well and the plate was re-incubated for $20 \mathrm{~min}$. A change of color from blue (oxidized) to pink (reduced) indicated the growth of fungi [34,35]. The MIC was defined as the lowest concentration of each compound that prevented this change in color.

\subsection{Determination of Minimum Fungicidal Concentration (MFC)}

One-hundred microliters of the blue wells' aliquots corresponding to the MIC and upper MIC values of BCN-E 50-52 and thymol were cultured on Sabouraud dextrose agar plates and incubated at $35^{\circ} \mathrm{C}$ for $48 \mathrm{~h}$. The lowest concentration that prevented visible growth was regarded as the MFC. The MFC/MIC ratio results were interpreted to fungistatic (MFC/MIC $\geq 4$ ) or fungicidal activity (MFC/MIC 4) of compounds [36].

\subsection{Agar Disk Diffusion}

The agar disc diffusion method was performed based on CLSI to assay the inhibition zone diameters of BCN-E 50-52 against E. coli, a Gram-negative bacteria, and S. aureus, a Gram-positive bacteria [37]. Briefly, blank disks $(6 \mathrm{~mm})$ were placed on prepared BHI agar plates inoculated with adjusted 0.5 McFarland turbidity inocula. Then, $20 \mu \mathrm{L}$ of dialyzed BCN-E5 0-52 with different concentrations were poured on blank disks. Ampicillin $(10 \mu \mathrm{g} / \mathrm{mL})$ disks were placed on the center of plates for comparison. Inhibitory zones were measured after $24 \mathrm{~h}$ of incubation at $37^{\circ} \mathrm{C}$. All tests were performed in triplicate, and the mean of the inhibition diameters expressed were reported [38].

\subsection{Synergy Study}

A checkerboard dilution test was applied to evaluate the synergistic effects of BCN-E 50-52 and thymol against all tested microorganisms [20]. The fractional inhibitory concentration (FIC) was calculated according to the following formula: FIC of each drug (FIC) $=(\mathrm{MIC}$ of drug in combination)/(its MIC value). The FIC index (FICI) values were calculated using the following equation: $\mathrm{FICI}=\mathrm{FIC}_{\mathrm{A}}+\mathrm{FIC}_{\mathrm{B}}[20]$.

The interpretation is as follows: synergy, 0.5; partial synergy, 0.5-0.75; additive effect, 0.76-1.0; indifference, 1.0-4.0; and antagonism, 4.0 [39,40]. The fractional bactericidal concentration index (FBCI) is the sum of the FBCs of each of the compounds and is calculated and interpreted the same as mentioned above for FIC [41].

\subsection{Time-Kill Curves}

A time-kill assay was performed on $10 \mathrm{~mL}$ of $E$. coli as an important Gram-negative bacteria, and S. aureus, as the most common Gram-positive bacteria in food poisoning, with a starting inoculum of $10^{6} \mathrm{CFU} / \mathrm{mL}$ in the exponential phase. BCN-E 50-52 and thymol with $2 \times$ MIC concentrations alone or in combination were applied for investigation of their single and combination impacts on cell viability. Samples were taken at 0,20,40,60, 80, 100, and 120 min after incubation and plated on BHI agar for colony counting. The detraction pattern of viable bacteria cell numbers and synergistic effects were 
determined after $24 \mathrm{~h}$ of incubation at $37^{\circ} \mathrm{C}$ [42]. These experiments were performed in duplicate. Positive controls for the assay included ampicillin $(10 \mu \mathrm{g} / \mathrm{mL})$, and bacterial cultures without any agents were included as negative controls [43,44].

A reduction of $\geq 1 \log _{10}$ relative to the initial inoculum indicates antimicrobial activity. In the synergism assay, a reduction of $\geq 2 \log _{10}$ and $1 \leq \log _{10} \leq 2$ were considered as synergistic and additive, respectively [41].

\subsection{Growth Curve}

In short, mid-log phase bacterial cultures with a turbidity of 0.6 at $600 \mathrm{~nm}$ were diluted in $\mathrm{MHB}$, achieving an OD600 of $=0.2\left(10^{8} \mathrm{CFU} / \mathrm{mL}\right)$. After that, $200 \mu \mathrm{L}$ of bacterial cultures were allocated to separate culture tubes and $2 \times$ MIC concentrations of BCN-E 50-52 and thymol alone or in combination were added to particular tubes. Tubes were incubated at $37^{\circ} \mathrm{C}$. At specific time intervals, turbidity was measured at $600 \mathrm{~nm}$. The assay was carried out in duplicate [40].

\subsection{SEM Microscopy}

Overnight cultures of E. coli and S. aureus were adjusted to OD $0.1\left(1 \times 10^{8}\right.$ cells $\left./ \mathrm{mL}\right)$ at $600 \mathrm{~nm}$ and were then diluted with BHI medium to achieve $1 \times 10^{6} \mathrm{CFU} / \mathrm{mL}$ cell density. Afterwards, bacterial cells were treated with thymol and BCN-E 50-52 at the determined FIC values for $2 \mathrm{~h}$ at $37^{\circ} \mathrm{C}$. Untreated controls were prepared in BHI medium with the same cell density. The bacterial cells were centrifuged at $12,000 \times g$ for $15 \mathrm{~min}$, then washed two or three times and resuspended in sterile PBS. Ten microliters of suspension was spread onto a microscope slide and fixed in $2.5 \%$ glutaraldehyde. Then, samples were coated with gold. The changes in cell morphology were analyzed by SEM (AIS2100, Seron Technologies, Uiwang-si, Gyeonggi-do, Korea) $[45,46]$.

\subsection{Statistical Analysis}

All statistical analyses were performed using SPSS (Version 16.0; SPSS, Inc., Chicago, IL, USA) software. Data analysis was presented as means \pm standard deviations. Statistical significance was defined as $p 0.05$. Mean values analysis was calculated by a Tukey test at the 0.05 level of significance. All related graphs were created with Microsoft Excel 2010.

Acknowledgments: This study was conducted with financial assistance from Arak University of Medical Sciences, Iran, and we are grateful for their invaluable contribution to this study.

Author Contributions: Shohreh Fahimirad, Hamid Abtahi, Syed Hadi Razavi, Houshang Alizadeh and Mansour Ghorbanpour conceived and designed the experiments; Shohreh Fahimirad performed the experiments; Shohreh Fahimirad analyzed the data; Hamid Abtahi contributed reagents/materials/analysis tools; and Shohreh Fahimirad wrote the paper.

Conflicts of Interest: The authors declare no conflict of interest.

\section{References}

1. Rai, M.; Pandit, R.; Gaikwad, S.; Kövics, G. Antimicrobial peptides as natural bio-preservative to enhance the shelf-life of food. J. Food Sci. Technol. 2016, 53, 3381-3394. [CrossRef] [PubMed]

2. $\quad$ Sung, S.Y.; Sin, L.T.; Tee, T.T.; Bee, S.T.; Rahmatb, A.R.; Rahmanb, W.A.W.A.; Tana, A.-C.; Vikhraman, M. Antimicrobial agents for food packaging applications. Trends Food Sci. Technol. 2013, 33, 110-123. [CrossRef]

3. Gautam, N.; Sharma, N. Bacteriocin: Safest approach to preserve food products. Indian J. Microbiol. 2009, 49, 204-211. [CrossRef] [PubMed]

4. Cui, Y.; Zhang, C.; Wang, Y.; Shi, J.; Zhang, L.; Ding, Z.; Qu, X.; Cui, H. Class IIa bacteriocins: Diversity and new developments. Int. J. Mol. Sci. 2012, 13, 16668-166707. [CrossRef] [PubMed]

5. Svetoch, E.A.; Eruslanov, B.V.; Perelygin, V.V.; Mitsevich, E.V.; Mitsevich, I.P.; Borzenkov, V.N.; Levchuk, V.P.; Svetoch, O.E.; Kovalev, Y.N.; Stepanshin, Y.G.; et al. Diverse antimicrobial killing by Enterococcus faecium E 50-52. bacteriocin. J. Agric. Food Chem. 2008, 56, 1942-1948. [CrossRef] [PubMed] 
6. Svetoch, E.A.; Eruslanov, B.V.; Kovalev, Y.N.; Mitsevich, E.V.; Mitsevich, I.P.; Levchuk, V.P.; Fursova, N.K.; Perelygin, V.V.; Stepanshin, Y.G.; Teymurasov, M.G.; et al. Antimicrobial Activities of Bacteriocins E 50-52 and B 602 Against Antibiotic-Resistant Strains Involved in Nosocomial Infections. Probiotics Antimicrob. Proteins 2009, 1. [CrossRef] [PubMed]

7. Klint, J.K.; Senff, S.; Saez, N.J.; Seshadri, R.; Lau, H.Y.; Bende, N.S.; Undheim, E.A.; Rash, L.D.; Mobli, M.; King, G.F. Production of Recombinant Disulfide-Rich Venom Peptides for Structural and Functional Analysis via Expression in the Periplasm of E. coli. PLoS ONE 2013. [CrossRef] [PubMed]

8. Pane, K.; Durante, L.; Pizzo, E.; Varcamonti, M. Rational Design of a Carrier Protein for the Production of Recombinant Toxic Peptides in Escherichia coli. PLoS ONE 2016, 11. [CrossRef] [PubMed]

9. Audic, J.L.; Chaufer, B.; Daufin, G. Non-food applications of milk components and dairy co-products: A review. Le Lait 2003, 83, 417-438. [CrossRef]

10. Shapira, A.; Assaraf, Y.G.; Epstein, D.; Livney, Y.D. Beta-casein Nanoparticles as an Oral Delivery System for Chemotherapeutic Drugs: Impact of Drug Structure and Properties on Co-assembly. Pharm. Res. 2010, 27, 2175-2186. [CrossRef] [PubMed]

11. Esmaili, M.; Ghaffari, S.M.; Moosavi-Movahedi, Z.; Atri, M.; Sharifizadeh, A.; Farhadi, M.; Yousefi, R.; Chobert, J.M.; Haertlé, T.; Moosavi-Movahedi, A.A. Beta casein-micelle as a nano vehicle for solubility enhancement of curcumin; food industry application. LWT Food Sci. Technol. 2011, 44, 2166-2172. [CrossRef]

12. Follows, D.; Holt, C.; Nylander, T.; Thomas, R.K.; Tiberg, F. Beta-casein adsorption at the silicon oxide-aqueous solution interface: Calcium ion effects. Biomacromolecules 2004, 5, 319-325. [CrossRef] [PubMed]

13. Olof, S.; Anil, K.S.; Marie, S. Adsorption of $\beta$-casein to hydrophilic silica surfaces. Effect of $\mathrm{pH}$ and electrolyte. Food Hydrocoll. 2014, 36, 332-338.

14. Szyk-Warszyńska, L.; Kilan, K.; Socha, R.P. Characterization of casein and poly-L-arginine multilayer films. J. Colloid Interface Sci. 2014, 423, 76-84. [CrossRef] [PubMed]

15. Valencia-Chamorro, S.A.; Palou, L.; Del Río, M.A.; Pérez-Gago, M.B. Antimicrobial edible films and coatings for fresh and minimally processed fruits and vegetables: A review. Crit. Rev. Food Sci. Nutr. 2011, 51, 872-900. [CrossRef] [PubMed]

16. Damodaran, S.; Sengupta, T. Dynamics of competitive adsorption of alphas-casein and beta-casein at planar triolein-water interface: Evidence for incompatibility of mixing in the interfacial film. J. Agric. Food Chem. 2003, 51, 1658-1665. [CrossRef] [PubMed]

17. Flórez-Castillo, J.M.; Perullini, M.; Jobbágy, M.; Cano, H. Enhancing Antibacterial Activity against Escherichia coli K-12 of Peptide Ib-AMP4 with Synthetic Analogues. Int. J. Pept. Res. Ther. 2014, 20, 365-369. [CrossRef]

18. Wang, Q.; Fu, W.; Ma, Q; Yu, Z.; Zhang, R. Production of bacteriocin E 50-52 by small ubiquitin-related modifier fusion in Escherichia coli. Pol. J. Microbiol. 2013, 62, 345-350. [PubMed]

19. Jiang, Z.; Vasil, A.I.; Hale, J.D.; Hancock, R.E.; Vasil, M.L.; Hodges, R.S. Effects of net charge and the number of positively charged residues on the biological activity of amphipathic $\alpha$-helical cationic antimicrobial peptides. Biopolymers 2008, 90, 369-383. [CrossRef] [PubMed]

20. Zhao, X.; Shi, C.; Meng, R.; Liu, Z.; Huang, Y.; Zhao, Z.; Guo, N. Effect of nisin and perilla oil combination against Listeria monocytogenes and Staphylococcus aureus in milk. J. Food Sci. Technol. 2016, 53, 2644-2653. [CrossRef] [PubMed]

21. Ramos, M.; Beltrán, A.; Peltzer, M.; Valente, A.J.M.; Garrigós, M.C. Release and antioxidant activity of carvacrol and thymol from polypropylene active packaging films. LWT-Food Sci. Technol. 2014, 58, 470-477. [CrossRef]

22. Trombetta, D.; Castelli, F.; Sarpietro, M.G.; Venuti, V.; Cristani, M.; Daniele, C.; Saija, A.; Mazzanti, G.; Bisignano, G. Mechanisms of Antibacterial Action of Three Monoterpenes. Antimicrob. Agents Chemother. 2005, 49, 2474-2478. [CrossRef] [PubMed]

23. Froger, A.; Hall, J.E. Transformation of Plasmid DNA into E. coli Using the Heat Shock Method. J. Vis. Exp. 2007, 6. [CrossRef] [PubMed]

24. Farhangnia, L.; Ghaznavirad, E.; Mollaee, N.; Abtahi, H. Cloning, Expression, and Purification of Recombinant Lysostaphin from Staphylococcus simulans. Jundishapur J. Microbiol. 2014, 7. [CrossRef] [PubMed]

25. Sivashanmugam, A.; Murray, V.; Cui, C.; Zhang, Y.; Wang, J.; Li, Q. Practical protocols for production of very high yields of recombinant proteins using Escherichia coli. Protein Sci. 2009, 185, 936-948. [CrossRef] [PubMed] 
26. Molaee, N.; Abtahi, H.; Mosayebi, G. Expression of Recombinant Streptokinase from Streptococcus P yogenes and Its Reaction with Infected Human and Murine Sera. Iran J. Basic Med. Sci. 2013, 16, 985-989. [PubMed]

27. Yamaguchi, H.; Miyazaki, M. Refolding Techniques for Recovering Biologically Active Recombinant Proteins from Inclusion Bodies. Biomolecules 2014, 4, 235-251. [CrossRef] [PubMed]

28. Choi, H.; Chakraborty, S.; Liu, R.; Gellman, S.H.; Weisshaar, J.C. Medium Effects on Minimum Inhibitory Concentrations of Nylon-3 Polymers against E. coli. PLoS ONE 2014, 9. [CrossRef] [PubMed]

29. Qiu, J.; Wang, D.; Xiang, H.; Feng, H.; Jiang, Y.; Xia, L.; Dong, J.; Lu, J.; Yu, L.; Deng, X. Subinhibitory concentrations of thymol reduce enterotoxins A and B and $\alpha$-hemolysin production in Staphylococcus aureus isolates. PLOS ONE 2010, 5. [CrossRef] [PubMed]

30. CLSI Document M07-A10. Methods for Dilution Antimicrobial Susceptibility Tests for Bacteria that Grow Aerobically; Clinical and Laboratory Standards Institute: Wayne, PA, USA, 2015.

31. Elshikh, M.; Ahmed, S.; Funston, S.; Dunlop, P.; McGaw, M.; Marchant, R.; Banat, I.M. Resazurin-based 96-well plate microdilution method for the determination of minimum inhibitory concentration of biosurfactants. Biotechnol. Lett. 2016, 38, 1015-1019. [CrossRef] [PubMed]

32. CLSI Document M27-S4. Method for Broth Dilution Antifungal Susceptibility Testing of Yeasts; Fourth Informational Supplement; Clinical and Laboratory Standards Institute: Wayne, PA, USA, 2012.

33. CLSI Document M38-A2. Reference Method for Broth Dilution Antifungal Susceptibility Testing of Filamentous FungiApproved Standard, 2nd Ed.; Clinical and Laboratory Standards Institute: Wayne, PA, USA, 2008.

34. Jang, W.S.; Kim, H.K.; Lee, K.Y.; Kim, S.A.; Han, Y.S.; Lee, I.H. Antifungal activity of synthetic peptide derived from halocidin, antimicrobial peptide from the tunicate, Halocynthia aurantium. FEBS Lett. 2006, 580, 1490-1496. [CrossRef] [PubMed]

35. Mania, D.; Hilpert, K.; Ruden, S.; Fischer, R.; Takeshita, N. Screening for antifungal peptides and their modes of action in Aspergillus nidulans. Appl. Environ. Microbiol. 2016, 76, 7102-7108. [CrossRef] [PubMed]

36. De Castro, R.D.; de Souza, T.M.; Bezerra, L.M.; Ferreira, G.L.; Costa, E.M.; Cavalcanti, A.L. Antifungal activity and mode of action of thymol and its synergism with nystatin against Candida species involved with infections in the oral cavity: An in vitro study. BMC Complement. Altern. Med. 2015, 15. [CrossRef] [PubMed]

37. CLSI Document M100-S25. Performance Standards for Antimicrobial Susceptibility Testing; Twenty-First Informational Supplement; Clinical and Laboratory Standards Institute: Wayne, PA, USA, 2008.

38. Iqbal, J.; Siddiqui, R.; Kazmi, S.U.; Khan, N.A. A Simple Assay to Screen Antimicrobial Compounds Potentiating the Activity of Current Antibiotics. Biomed. Res. Int. 2013, 2013. [CrossRef] [PubMed]

39. Seesom, W.; Jaratrungtawee, A.; Suksamrarn, S.; Mekseepralard, C.; Ratananukul, P.; Sukhumsirichart, W. Antileptospiral activity of xanthones from Garcinia mangostana and synergy of gamma-mangostin with penicillin G. BMC Complement. Altern. Med. 2013, 13, 182-188. [CrossRef] [PubMed]

40. Cha, J.D.; Lee, J.H.; Cho, K.M.; Choi, S.M.; Park, J.H. Synergistic Effect between Cryptotanshinone and Antibiotics against Clinic Methicillin and Vancomycin-Resistant Staphylococcus aureus. Evid. Based Complement. Alternat. Med. 2014, 2014, 450572-450588. [CrossRef] [PubMed]

41. Lora-Tamayo, J.; Murillo, O.; Bergen, P.J.; Nation, R.L.; Poudyal, A.; Luo, X.; Yu, H.Y.; Ariza, J.; Li, J. Activity of colistin combined with doripenem at clinically relevant concentrations against multidrug-resistant Pseudomonas aeruginosa in an in vitro dynamic biofilm model. J. Antimicrob. Chemother. 2014, 69, 2434-2442. [CrossRef] [PubMed]

42. Ghrairi, T.; Hani, K. Enhanced bactericidal effect of enterocin A in combination with thyme essential oils against L. monocytogenes and E. coli O157:H7. J. Food Sci. Technol. 2013, 52, 2148-2156. [CrossRef] [PubMed]

43. Mohan, K.V.; Rao, S.S.; Gao, Y.; Atreya, C.D. Enhanced antimicrobial activity of peptide-cocktails against common bacterial contaminants of ex vivo stored platelets. Clin. Microbiol. Infect. 2014, 20, 39-46. [CrossRef] [PubMed]

44. Rudilla, H.; Fusté, E.; Cajal, Y.; Rabanal, F.; Vinuesa, T.; Viñas, M. Synergistic Antipseudomonal Effects of Synthetic Peptide AMP38 and Carbapenems. Molecules 2016, 21. [CrossRef] [PubMed]

45. Burt, S.A.; Reinders, R.D. Antibacterial activity of selected plant essential oils against Escherichia coli O157:H7. Lett. Appl. Microbiol. 2003, 36, 162-167. [CrossRef] [PubMed] 
46. Zengin, H.; Baysal, A.H. Antibacterial and Antioxidant Activity of Essential Oil Terpenes against Pathogenic and Spoilage-Forming Bacteria and Cell Structure-Activity Relationships Evaluated by SEM Microscopy. Molecules 2014, 19, 17773-17798. [CrossRef] [PubMed]

Sample Availability: Samples of the compounds are available from the authors.

(a) 1

(C) 2017 by the authors. Licensee MDPI, Basel, Switzerland. This article is an open access article distributed under the terms and conditions of the Creative Commons Attribution (CC BY) license (http:/ / creativecommons.org/licenses/by/4.0/). 